\title{
PEMANFAATAN TANAMAN MINYAK ATSIRI SEBAGAI PENGENDALI HAMA TIKUS PADI (BIOPESTISIDA) DI KABUPATEN SUKABUMI
}

\author{
Lela Lailatul Khumaisah $^{1 *}$, Lela Mukmilah Yuningsih ${ }^{1}$, dan Asep Kadarohman ${ }^{2}$ \\ ${ }^{1)}$ Program Studi Kimia, Fakultas Sains dan Teknologi, Universitas Muhammadiyah Sukabumi, Jl. R. Syamsudin, S. \\ H. No. 50 Sukabumi 43113 \\ ${ }^{2)}$ Program Studi Kimia, Departemen Pendidikan Kimia, Universitas Pendidikan Indonesia \\ Jl. Dr. Setiabudhi No. 229 Bandung 40154 \\ Email: "lelakhumaisah@ummi.ac.id, lelathea@ummi.ac.id, kadar@upi.edu
}

\begin{abstract}
Abstrak
Kandungan kimia dalam berbagai jenis minyak atsiri mempunyai aktivitas terhadap mikroba, hama tanaman, serangga vektor patogen pada manusia dan hewan, di antaranya adalah Mentha arvensis dan Mentha piperita (tanaman mint) yang memiliki efek antifertiliti dan antibakteri, Vetiveria zizanoides (akar wangi) dapat menolak serangga, Cymbopogon nardus (serai wangi) mempunyai aktivitas terhadap bakteri patogen tanaman dan antijamur, serta Rosmarinus officinalis (rosemary) dapat mempengaruhi aktivitas lokomotor tikus dan antibakteri. Minyak atsiri efektif terhadap organisme sasaran, kompatibel, aman dan tidak toksik, sehingga mempunyai potensi yang sangat besar untuk dikembangkan sebagai pestisida nabati (biopestisida). Di sisi lain, hama dan penyakit merupakan masalah yang selalu mengganggu para petani padi, di antaranya di desa Sukaresmi dan Kebon Pedes kabupaten Sukabumi. Oleh karena itu, telah dilakukan pemanfaatan keempat tanaman minyak atsiri tersebut untuk mengendalikan hama tikus padi melalui dua cara analisis, pertama dengan pengamatan banyaknya hama tikus dan proses pertumbuhan tanaman padi pada lahan yang ditanami dengan minyak atsiri dan tanaman padi saja sebagai kontrol. Cara kedua dengan menggunakan metode Rancangan Acak Lengkap (RAL). Berdasarkan hasil pengamatan, pertumbuhan dan perkembangan tanaman minyak atsiri sebagai tanaman sela padi berjalan normal dan dampaknya terhadap hama tanaman padi terutama tikus cukup signifikan dengan berkurang populasinya di sekitar area penanaman.
\end{abstract}

Kata kunci: Mint, serai wangi, rosemary, minyak atsiri, biopestisida

\section{PENDAHULUAN}

Sukabumi merupakan kabupaten terbesar di wilayah provinsi Jawa Barat, dengan luas $4.162 \mathrm{~km}^{2}$ atau 11,21\% dari luas Jawa Barat dan 3,01\% dari luas seluruh pulau jawa sesuai data dari Portal Resmi Kabupaten Sukabumi (RPJMD Kab. Sukabumi, 2016). Sukaresmi dan Kebon Pedes adalah sebuah desa di Kabupaten Sukabumi, Jawa Barat dengan sebagian besar mata pencaharian penduduknya adalah buruh dan petani. Salah satu jenis komoditas yang utama adalah padi, hal ini didukung oleh kekayaan alam yang dimiliki seperti pada Gambar 1 berikut.

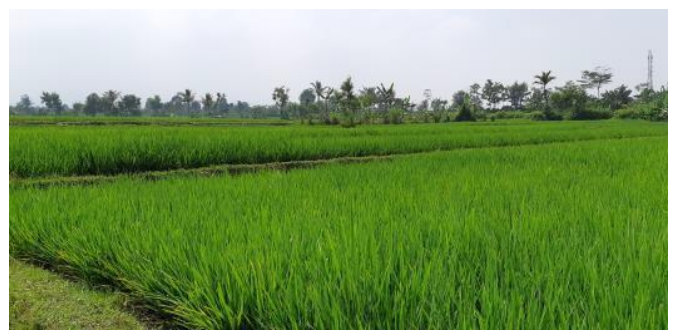

Gambar 1. Kondisi lahan sawah di Desa Sukaresmi.

Teknologi Tepat Guna 
Namun, upaya meningkatkan produksi pertanian padi di Indonesia termasuk di kedua desa tersebut berhadapan dengan berbagai masalah dan penghambat berupa faktor abiotis dan biotis. Faktor abiotis yang terpenting berupa penurunan kesuburan lahan, kekeringan dan kondisi yang kurang baik dari iklim dan cuaca. Adapun faktor biotis berupa organisme pengganggu tanaman, yaitu hama, penyakit, dan gulma.

Hama dan penyakit merupakan masalah yang selalu mengganggu tanaman para petani serta menjadi sumber masalah terhadap keberhasilan dalam mengembangkan tanaman selama ini. Padi merupakan salah satu komoditas penting yang harus tetap dilestarikan guna memenuhi kebutuhan pangan Indonesia karena sebagai sumber makanan pokok. Jika hama dan penyakit pada tanaman padi tidak segera diatasi dan ditanggulangi, maka para petani akan gagal panen dan akhirnya akan mengalami kerugian. Padi merupakan tanaman yang rentan terhadap hama yang dapat mengakibatkan produksi lahan berkurang, salah satunya adalah tikus. Oleh karena itu, perlu upaya untuk mengendalikan hama tikus tersebut agar diperoleh hasil panen yang melimpah dan optimal.

Di sisi lain, Indonesia merupakan negara tropis terbesar kedua setelah Brazil yang memiliki keanekaragaman hayati yang melimpah di dunia. Hal ini mendukung Indonesia sebagai negara megadiversity dengan sumberdaya alamnya. Kekayaan alam ini patut dikelola dan dimanfaatkan oleh kita untuk kesejahteraan dan kemakmuran masyarakat, termasuk dalam pencarian pembasmi hama padi terutama tikus. Adanya keanekaragaman hayati sebagai sumber keanekaragaman molekul inilah yang menjadi modal awal untuk perkembangan dan kebaruan ilmu pengetahuan, terutama kimia organik bahan alam yang di dalamnya mencakup minyak atsiri.

Di Indonesia khususnya telah dikenal sekitar 40-an jenis tanaman penghasil minyak atsiri (Dewan Atsiri Indonesia, 2006). Minyak atsiri tersebut antara lain minyak sereh, daun cengkeh, akar wangi, daun nilam dan minyak atsiri lainnya yang kebanyakan diekspor ke Amerika, Jepang dan Eropa. Berbicara mengenai minyak atsiri, tidak lepas dari membahas masalah bau dan aroma, karena fungsi minyak atsiri sebagai pengharum tubuh, ruangan, sabun, kosmetik, pemberi cita rasa pada makanan maupun produk rumah tangga lainnya (Agusta, A., 2002). Selain itu, seiring dengan perkembangan teknologi dan ilmu pengetahuan, fungsi minyak atsiri dan senyawa turunannya semakin meluas yang dapat digunakan sebagai feromon, aditif biodisel, antioksidan, polimer, aromaterapi, penyerap logam, sun screen block dan banyak lagi kegunaan lainnya.

Beberapa minyak atsiri telah dikenal mempunyai aktivitas biologi terhadap mikroba maupun serangga hama dan vektor patogen yang merugikan manusia, hewan, dan tanaman (Isman, M. B., 2000; Adyana, I. G. S., dkk., 2012; Hartati, S.Y., 2012; dan Prasetyo, H. D., dkk., 2013). Properti minyak atsiri tersebut berhubungan dengan senyawa yang dikandungnya terutama dari golongan terpenoid, alkohol, aldehid, dan fenol (Burt, S., 2007). Dari penelitian yang telah dilakukan Sharma, N. dan Jacob, D. pada tahun 1996, 1997 dan 2002 diketahui bahwa ekstrak air, petroleum eter, dan metanol dari daun Mentha arvensis memiliki efek antifertilitas terhadap tikus jantan. Selain itu, Da Silva Bezerra Guerra, K.S., et. al., 2012 menyebutkan bahwa minyak atsiri dari tanaman Mentha memiliki toksisitas terhadap embrio dan janin pada tikus Wistar.

Program ini merupakan pengembangan yang telah diinisiasi oleh Kadarohman, A., dkk. (2017) termasuk penulis di dalamnya yang dilakukan di daerah Cicalengka Kabupaten Bandung. Oleh karena itu, pada kesempatan ini akan dilakukan pemanfaatan tanaman Mentha arvensis dan minyak atsiri lain sebagai kajian ilmu dan perluasan program pengabdian kepada masyarakat khususnya para petani di Desa Sukaresmi Cisaat dan Kebon Pedes untuk mengendalikan hama padi terutama tikus, sehingga kesinambungan program ini di masa mendatang akan tetap terjaga dan semakin meluas mengingat dampak yang dapat diperoleh masyarakat cukup besar.

\section{METODE}

Program ini dilakukan mulai dari budidaya tanaman minyak atsiri yang berpotensi sebagai pestisida nabati terutama tikus sebagai tanaman sela tanaman padi sampai memproduksi minyak atsirinya, sehingga diharapkan akan memperoleh

Teknologi Tepat Guna

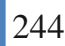


keuntungan ganda, yaitu pembasmian hama padi dan tanaman minyak atsiri. Dalam pelaksanaannya digunakan demplot untuk uji coba (Gambar 2) dan pengaplikasian ilmu kimia minyak atsiri dalam bidang pertanian serta produksi tanaman minyak atsiri.

\begin{tabular}{|c|c|c|c|}
\hline $\begin{array}{c}\text { Padi dengan } \\
\text { Mentha } \\
\text { arvensis }\end{array}$ & $\begin{array}{c}\text { Padi dengan } \\
\text { Rosemary }\end{array}$ & $\begin{array}{c}\text { Padi dengan } \\
\text { Serai Wangi }\end{array}$ & $\begin{array}{c}\text { Padi dengan } \\
\text { Mentha } \\
\text { piperita }\end{array}$ \\
$\begin{array}{c}\text { Demplot } \\
\text { Lahan I }\end{array}$ & $\begin{array}{c}\text { Demplot } \\
\text { Lahan II }\end{array}$ & $\begin{array}{c}\text { Demplot } \\
\text { Lahan III }\end{array}$ & $\begin{array}{c}\text { Demplot } \\
\text { Lahan IV }\end{array}$ \\
\hline
\end{tabular}

Gambar 2. Demplot uji coba tanaman minyak atsiri sebagai tanaman sela padi.

Selain berupaya untuk menanggulangi hama padi, dari hasil pendampingan program ini akan dihasilkan beberapa jenis tanaman minyak atsiri yang merupakan komoditas ekspor Indonesia. Harapan di masa yang akan datang, para petani di Desa Sukaresmi dan Kebon pedes dapat mengembangkan program ini secara lebih luas sehingga akan mampu juga menjadi sentra penghasil tanaman minyak atsiri, dengan begitu ketersediaan komoditas ini akan terus terjaga mengingat kebutuhan dunia akan minyak atsiri semakin meningkat.

\section{HASIL DAN PEMBAHASAN}

\section{Pembibitan Tanaman Minyak Atsiri}

Tanaman minyak atsiri yang digunakan ada 4 macam, yakni yang pertama dua jenis Mentha (tanaman mint); Mentha arvensis dan Mentha piperita, serai wangi (Cymbopogon nardus), dan rosemary. Tanaman Mentha atau juga dikenal dengan tanaman mentol ini bukan merupakan tanaman asli Indonesia, sehingga diperlukan pembibitan secara terus-menerus agar terjaga ketersediaannya. Mentha arvensis merupakan tanaman Mentha asli Indonesia yang berasal dari hibrida dari water mint (Mentha aquatica) dan spearmint (Mentha spicata), sehingga berpeluang dibudidayakan di Indonesia. Melalui program ini, telah dibudidayakan tanaman Mentha arvensis dan Mentha piperita sebagai tanaman sela pada tanaman padi yang ditanam di area sawah (Gambar 3 dan 4). Bibit tanaman ini berasal dari daerah Lembang, di perkebunan Manoko yang dikembangkan oleh Kementerian Pertanian.

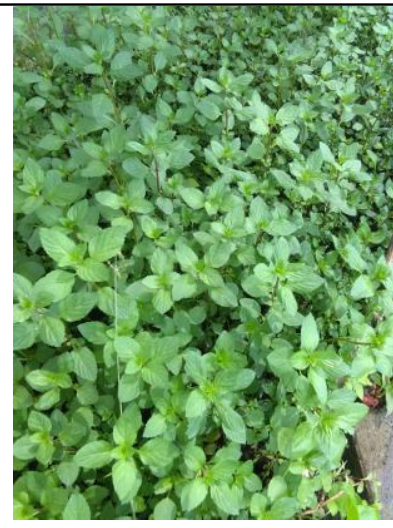

Gambar 3. Pembibitan tanaman Mentha arvensis.

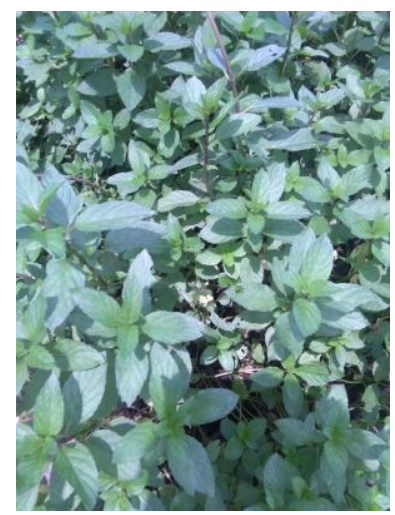

Gambar 4. Pembibitan tanaman Mentha piperita.

Selain kedua jenis tanaman Mentha di atas, tanaman minyak atsiri lain yang dimanfaatkan sebagai pengendali hama tikus padi adalah serai wangi dan rosemary. Karena telah diketahui bahwa kedua tanaman tersebut memiliki berbagai bioaktivitas di antaranya sebagai biopestisida. Proses pembibitan dari kedua tanaman minyak atsiri ini dapat dilihat pada Gambar 5 dan 6.

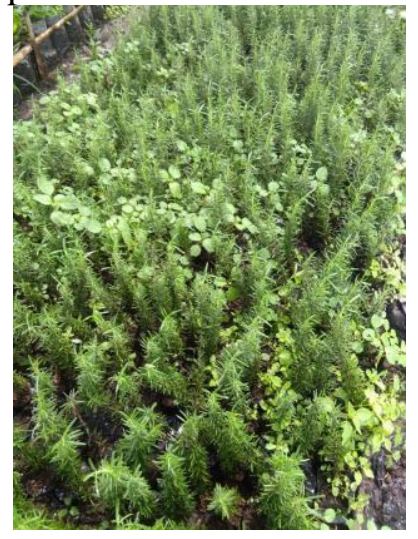

Gambar 5. Pembibitan tanaman rosemary.

Teknologi Tepat Guna 


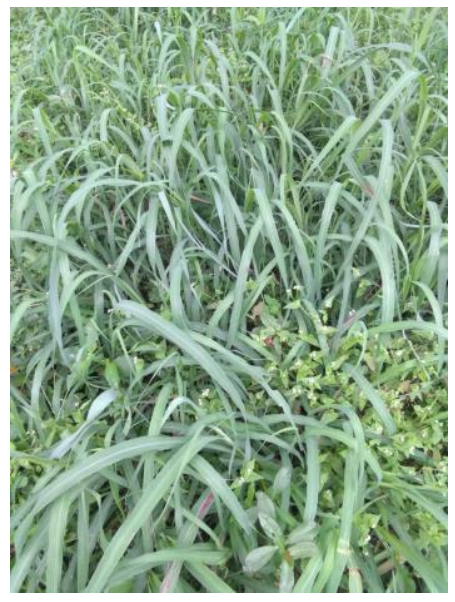

Gambar 6. Pembibitan tanaman serai wangi.

\section{Penanaman Tanaman Minyak Atsiri sebagai Tanaman Sela Padi}

Pada saat adaptasi, keempat tanaman minyak atsiri di lingkungan baru dinilai cukup baik dan lahan tanam sudah siap, maka selanjutnya dilakukan proses penanaman di area pinggir tanaman padi di sawah. Penanaman padi sudah dilakukan beberapa minggu sebelumnya, sehingga lahan sudah siap digunakan untuk penanaman. Luas area yang akan digunakan sebagai demplot sekitar $1.250 \mathrm{~m}^{2}$. Gambar 7 berikut merupakan salah satu proses penanaman minyak atsiri (rosemary) sebagai tanaman sela padi di area lahan sawah.

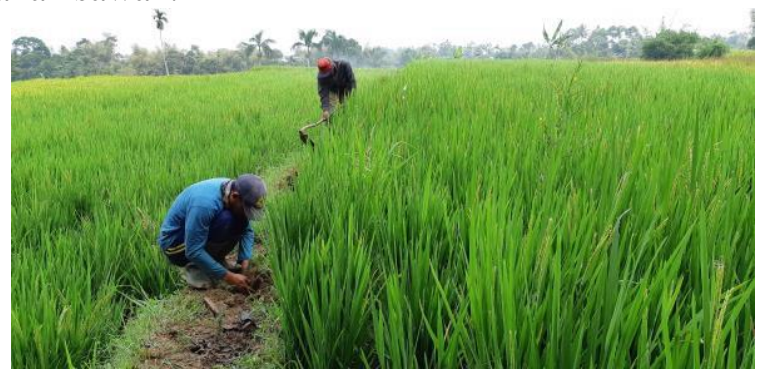

Gambar 7. Proses penanaman rosemary sebagai tanaman sela padi.

\section{Dampak Penanaman Tanaman Minyak Atsiri sebagai Pengendali Hama Tikus Padi}

Adanya tanaman minyak atsiri sebagai tanaman selapada padi cukup berpengaruh terhadap keberadaan hama tikus. Berdasarkan pengamatan, sejauh ini area lahan padi yang ditanami keempat tanaman minyak atsiri (Mentha arvensis, Mentha piperita, rosemary, dan serai wangi) terhindar dari menjangkitnya tikus yang merupakan salah satu hama penggangu bagi padi. Berbeda dengan area lahan lain yang tidak ditanami dengan tanaman minyak atsiri tersebut, keberadaan tikus cukup menggangu keberlangsungan tanaman padi dan yang ada di area lahan tersebut.

\section{KESIMPULAN}

Pengembangan Mentha arvensis, Mentha piperita, rosemary, dan serai wangi sebagai tanaman sela padi di Sukaresmi dan Kebon Pedes kabupaten Sukabumi sejauh ini berjalan baik dan cukup berhasil sebagai pengendali hama tikus. Oleh karena itu, potensi pengembangan program ini pun begitu menjanjikan di masa depan guna menambah nilai ekonomis para petani padi dan membantu mengatasi permasalahan hama yang selama ini menjadi gangguan dan hambatan di area lahan penanaman padi.

\section{UCAPAN TERIMAKASIH}

Penulis pada kesempatan ini mengucapkan terimakasih kepada Direktorat Riset dan Pengabdian Masyarakat (DRPM), Direktorat Jenderal Penguatan Riset dan Pengembangan, Kementerian Riset, Teknologi, dan Pendidikan Tinggi Republik Indonesia yang telah memberi sokongan dana dalam program ini.

\section{REFERENSI}

Adnyana, I.G.S., Sumiartha, K. dan Sudiarta, I.P. 2012. Efikasi Pestisida Nabati Minyak Atsiri Tanaman Tropis terhadap Mortalitas Ulat Bulu Gempinis. E-Jurnal Agroekoteknologi Tropika. ISSN: 2301-6515. Vol. 1, No. 1, Juli 2012. Pp 99-107.

Agusta, A. 2002. Minyak Atsiri Tumbuhan Tropika Indonesia. Bandung: Penerbit ITB.

Burt, S. 2007. Antibacterial activity of essential oils: potential application in food. Ph.D. thesis. Institute for Risk Assesment Sciences, Division of Veterinary Medicine, Public Health. Utrecht Univrsity. 
Da Silva Bezerra Guerra, K.S., Silva, R.L.C., Souza Maia, M.B., and Schwarz, A. 2012. Embryo and fetal toxicity of Mentha x villosa essential oil in Wistar rats. Pharmaceutical Biology. Volume 50, Issue 7, July 2012, Pages 871-877.

Dewan Atsiri Indonesia. 2016. Tanaman Atsiri. Tersedia: http://www.atsiriindonesia.com/tanaman-atsiri.php. [Online] 14 Februari 2017.

Hartati, S.Y. 2012. Prospek Pengembangan Minyak Atsiri sebagai Pestisida Nabati. Perspektif. Vol. 11 No. 1/Juni 2012. Hlm 45-58 ISSN: 14128004.

Isman, M. B. 2000. Plant essential oils for pest and disease management. Crop Protection. 19: 603608.

Kadarohman, A. 2017. Pemanfaatan Tanaman Mentha arvensis sebagai Pengendali Hama Tikus Padi. Laporan Akhir PKM Bidang Ilmu. Bandung: FPMIPA UPI. [Tidak Diterbitkan].

Prasetyo, H.D., Susila, I.W., dan Sumiartha, K. 2013. Efikasi Minyak Atsiri Sereh Dapur
(Cymbopogon citratus L.) terhadap Hama Ulat Daun Kubis (plutella xylostella L.) di Laboratorium. E-Jurnal Agroekoteknologi Tropika. ISSN: 2301-6515. Vol. 2, No. 2, April 2013. Pp 99-107.

RPJMD Kabupaten Sukabumi, 2016.

Sharma, N. and Jacob, D. 1996. Fertility suppression of the male mouse after administration of mint leaf extract. Phytotherapy Research. Volume 10, Issue 2, March 1996, Pages 175-177.

1997. Antispermatogenic effect of chromatographic fractions isolated from petroleum ether extract of Mentha arvensis leaf in the albino mouse. Phytotherapy Research. Volume 11, Issue 5, August 1997, Pages 386-388.

2002. Assessment of reversible contraceptive efficacy of methanol extract of Mentha arvensis L. leaves in male albino mice. Journal of Ethnopharmacology. Volume 80, Issue 1, 2002, Pages 9-13. 